\title{
Response of Native Tree Species to Ambient Air Quality
}

\author{
D. SARALA THAMBAVANI ${ }^{1}$ and J. MAHESWARI ${ }^{2 *}$ \\ ${ }^{1}$ Department of Chemistry, Sri Meenakshi Govt. College for Women, Madurai-625002, India \\ ${ }^{2}$ Department of Chemistry, V.H.N.S.N.College, Virudhunagar-626001, India \\ maheswarivaseekaran@gmail.com
}

Received 19 March 2013 / Accepted 30 April 2013

\begin{abstract}
The present investigation is the impact of air pollution on biochemical parameters of fifteen common tree species growing in different locations of Virudhunagar, Tamilnadu, India. The biochemical parameters taken into considerations were soluble protein content and total carbohydrate content of leaves. Variation in carbohydrate response to pollution stress may reflect difference in pollutants concentrations. Also, pollution tolerance has been associated with several biochemical characteristics such as higher concentrations of reducing sugars. It is evident from this research that the flow of the carbohydrates from the source to the sinks was affected by increased levels of studied gases. In addition, found a decrease in protein concentration under air pollution. Plant species differ in their response to air pollution. The results indicate that protein and carbohydrate content of leaves show considerable variation with the increase of intensity of air pollutants concentration.
\end{abstract}

Keywords: Air quality, leaf carbohydrate, protein content, Virudhunagar, air pollution.

\section{Introduction}

The earth's atmosphere is unique to the solar system because it has life for it, possible for the past three billion years. Air pollution is one of the serious problems faced by the people globally, especially in urban areas of developing countries like India. The urban air quality is continuously affected by emissions from both stationary and mobile sources ${ }^{1}$.Vehicles represent a major source of air pollutants such as, carbon monoxide(CO), nitrogen dioxide $\left(\mathrm{NO}_{2}\right)$, sulphur dioxide $\left(\mathrm{SO}_{2}\right)$ and particulate matters(PM).Emission from vehicles tend to increase due to increasing number of vehicles. Changes in the gaseous composition of earth have become a prime concern for today's world due to human activities. Ambient air pollution in several large cities of India is higher in the world ${ }^{2}$. According to an estimate dust pollution comprise around $40 \%$ of total air pollution problem in India. All these turn lead to an increase in the air pollution levels and have adverse effects on plants. Plants remove the air pollutants by three mechanisms absorption by the leaves, deposition of particulates and aerosols over the leaves and fallout of the particulates on the leeward side of the vegetation. Bio monitoring with plants is low cost and valuable method to evaluate the effect of different air and environment pollutants. Many trees are effective for trapping and absorbing air pollutants and act as sink to several air pollutants ${ }^{3}$. Hence it is more beneficial to see the 
impact of pollution on vegetation especially on tree. Carbohydrate is an important storage material for the plants. It is mainly produced in green leaves where mesophyll tissue is full of green pigments called chlorophylls. Therefore the level of these pigments and the amount of total carbohydrate present in leaf tissue indicate the photosynthetic efficiency of these plants. Protein is the main component of protoplasm and a primary growth factor for all living creatures. The main constituent of all the enzymes required for different physiological processes in protein. Therefore any fluctuation in carbohydrate or protein content of foliar tissues of dominant tree species can be treated as disturbances in overall growth of trees ${ }^{4}$. When exposed to air borne pollutants plants experienced physiological changes before exhibiting visible damage to leaves. Therefore, the present work was planned to assess effect of air pollution on common trees growing in Virudhunagar, to observe the variation in the total carbohydrate and protein content of the leaves.

\section{Experimental}

The present research work was mainly confined in Virudhunagar which is in southern part of Tamilnadu, India. Virudhunagar is a selection grade Municipality, spread over an area of 6.39 sq.km holding a population of 72,081 as of 2001(adopting population projection, it is interpolated the population of this town was 77449 in 2009). It is located at $9^{\circ} 35^{\prime}$ North latitude and $77^{\circ} 57^{\prime}$ East longitude and $101.3 \mathrm{~m}$ above mean sea level. The climate of the town is hot and dry throughout the year with April and May being the hottest months. The maximum temperature is above $38.5^{\circ} \mathrm{C}$, the minimum temperature is below $34.2^{\circ} \mathrm{C}$. The town receives rainfall mostly during Northeast monsoon, and the average rainfall is $780 \mathrm{~mm}$ per annum. For this study three sampling stations were selected and these stations were Madura coats colony (site-1), Pavaly (site 2), Perali (site 3). The selected locations categorized as residential area, heavy traffic area and industrial area respectively.

\section{Species selection and Monitoring}

Trees were randomly selected from the immediate vicinity of the station and were labeled for experiment. Three replicates of fully matured leaf samples of the selected plant species leaves were collected in a sterile polythene bags and the sample were maintained at $-20^{\circ} \mathrm{C}$ until further analysis. Fifteen species of evergreen and deciduous dicotyledonous trees, which are common in all the three stations in the study area, were selected for this purpose. 1) Delonix regia, 2) Tarmarindus indica, 3) Moringa olifera, 4) Azardiractaindica, 5) Mangifera indica, 6) Millingtonia hortensis, 7) Pongamia glabra, 8) Polyalthia longifolia, 9) Eugenia jambolana, 10) Pithecellobium dulce, 11) Ficus religiosa, 12) Ficus benghalensis, 13) Tectona grandis, 14) Eucalyptus globulus, 15) Ficus benjamina.

\section{Estimation of total soluble protein}

Bradford method has become a popular method for estimation of Proteins ${ }^{5}$. This method is based on the principle the proteins bind to coomassie brilliant blue G-250 in acid solution and form a complex whose extinction co-efficient $\left(Y_{\max }=595\right)$ is much greater that the free dye $\left(\mathrm{Y}_{\max }=465 \mathrm{~nm}\right)$. The Coomassie brilliant blue $\mathrm{G}-250$ or the serve blue-G appears as a pale-orange red in acid solution. The dye binds strongly to positively charged groups of proteins. As a result, blue colour is formed with an $\mathrm{Y}_{\max }$ at $595 \mathrm{~nm}$ (On binding to proteins the $\mathrm{Y}_{\max }$ is shifted from 465 to $595 \mathrm{~nm}$ )

\section{Determination of total carbohydrate}

Carbohydrates are first hydrolyzed into simple sugars using dilute hydrochloric acid. In hot acidic medium glucose is dehydrated to hydroxymethyl furfural. This forms compound 
with anthrone a green colored product with an absorption maximum at $630 \mathrm{~nm}^{6}$. A standard graph was drawn by plotting concentration of the standard on the $\mathrm{X}$-axis versus absorbance on the Y-axis. From the graph it was calculated the amount of carbohydrate present in the sample tube. Amount of carbohydrate present in $100 \mathrm{mg}$ of the sample $=$ [mg of glucose/ Volume of test sample] $\times 100$

A statistical treatment of the data carried out by using SPSS version 17 . Statistical difference of the means checked out using Analysis of Variance (ANOVA). The period of analysis ranged from May 2009-May 2011.

\section{Results and Discussion}

\section{Variation of carbohydrate content}

The result obtained for the effect of air pollution on total carbohydrate content of leaves of different plants is shown in Figure 1. Significant $(\mathrm{p}<0.01)$ decrease and increase in total carbohydrate content was observed in the samples collected from polluted area as compared to samples collected from control area.

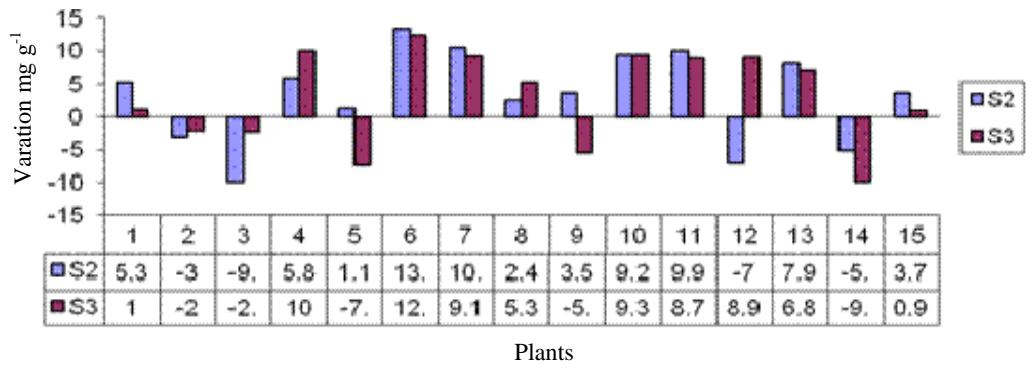

Figure 1. Variation of leaf's total carbohydrate content

Concentrations of total soluble sugars and starch decreased significantly in the trees from the polluted regions. On most occasions, the leaves were more susceptible to air toxicants, in relation to the carbohydrate content. At site 2 maximum decrease in soluble carbohydrate concentration was observed in leaves of $M$. hortensis $\left(13.4 \mathrm{mgg}^{-1}\right)$ and maximum increase was observed in M.olifera $\left(9.9 \mathrm{mgg}^{-1}\right)$. The main stress compensatory strategy in plants is to minimize damage from stress and the change in carbohydrate content. This observation was supported by the results obtained by Woo et al. ${ }^{7}$. Minimum decrease in the total soluble sugar was observed in the leaves of $M$. indica $\left(1.16 \mathrm{mgg}^{-1}\right)$ and minimum increase had shown by the plant $M$. olifera $\left(3 \mathrm{mgg}^{-1}\right)$. At site 2 the analyzed plants could be arranged in the decreasing order as $M$. hortensis $>P$. glabra $>F$. religiosa $>P$. dulce $>T$. grandis $>A$. indica $>D$. regia $>F$. benjamina $>E$. jambolana $>P$. longifolia $>M$. indica. Also the order of increase was $T$. indica $>E$. globulus $>F$. benhalensis followed by $M$. olifera at the site polluted mainly by automobile exhausts (Site 2 ).

At site 3, the maximum loss of total soluble carbohydrate including starch observed in the case of $M$. hortensis $\left(12.5 \mathrm{mgg}^{-1}\right)$. The maximum increase in the carbohydrate content was observed in the tree species E. globules $\left(9.9 \mathrm{mgg}^{-1}\right)$. Minimum decrease and minimum increase of carbohydrate content had observed in the tree species F. benjamina $\left(0.92 \mathrm{mgg}^{-1}\right)$, $T$. indica $\left(2 \mathrm{gg}^{-1}\right)$ respectively. It is obvious from the graph, tree species $M$. hortensis showed the highest decrease in carbohydrate content at both study sites $\left(\mathrm{S}_{1}\right.$ and $\left.\mathrm{S}_{2}\right)$. Among the selected trees, species like $M$. hortensis, P. glabra, F. religiosa, T. grandis and D. regia showed similar pattern of variation. They observed with lower value of total soluble sugar in 
$\mathrm{S}_{2}$ than $\mathrm{S}_{3}$. Analysis of results showed plants such as A. indica, $P$. longifolia showed similar trend and they exhibit maximum value of decrease at $S_{3}$ compared to $S_{2}$. Among the selected trees, species like $M$. indica, E. jambola and $F$. benhalensis observed with similar trend. They exhibit higher loss of carbohydrate content at $\mathrm{S}_{2}$ than at $\mathrm{S}_{3}$. Certain species like $T$. indica, $M$. olifera and E. globulus observed with increase in the value of carbohydrate content at both sites $S_{2}$ and $S_{3}$.

Soluble sugar is an important constituent and source of energy for all living organisms. Plants manufacture this organic substance during photosynthesis and breakdown during respiration. The concentration of soluble sugar is indicative of the physiological activity of a plant and it determines the sensitivity of plants to air pollution ${ }^{8}$. The sugar content was found to be reduced with the increase in the amount of air pollutants. Reduction in soluble sugar content in polluted stations can be attributed to increased respiration and decreased $\mathrm{CO}_{2}$ fixation because of chlorophyll deterioration.

The decrease in total sugar content of damaged leaves probably corresponded with the photosynthetic inhibition or stimulation of respiration rate. Higher starch accumulation in damaged leaves may be resulted both in the higher resistance of their photosynthetic apparatus and low starch export from the mesophyll. Acute exposure to oxidants reduced starch content and these findings are in agreement with Ziegler'. The increase of soluble sugars was also observed following chronic exposure stated by Miller et al., ${ }^{10}$.

In all patterns over the years, high concentration of air pollutants $\left(\mathrm{CO}_{2}, \mathrm{NO}_{2}\right)$ treatments increased the soluble, the insoluble and the total carbohydrate levels in the soybean leaves was reported by Rowland-Bamford et al., ${ }^{11}$. In most cases, decreases in the concentration of sugars were found which agreed with the previous work by researchers ${ }^{12}$.

In high concentration of air pollutants, it is likely that stomatal conductance was reduced thereby reducing $\mathrm{CO}_{2}$ uptake for photosynthesis by the leaves. While Tinge ${ }^{13}$ suggested that the retention of carbohydrates in leaves could cause reduction in photosynthesis by feedback inhibition and reduce the amount of assimilates for translocation to sinks within the plant. Variation in carbohydrate response to polluted air stress may reflect difference in carbohydrate concentrations. Also, tolerance has been associated with several biochemical characteristics such as concentrations of reducing sugars.

\section{Variation of total Protein content}

Decrease and increase in total protein content was observed in leaves collected from polluted sites as compared to control (Figure 2) and the result obtained was significant $(\mathrm{p}<0.001)$.

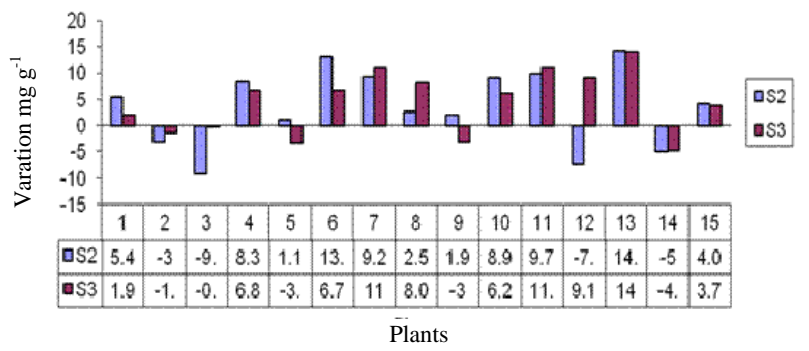

Figure 2. Variation of leaf's total Protein content

Plant protein is an essential component for the plant growth and development. Significant lowering of the protein content was recorded in all the plant species at the different sites in comparison to the control. At Site 2, the most affected species were Tectonagrandis (14 mgg $\left.{ }^{-1}\right)$, Millingtoniahortensis (13.1 $\left.\mathrm{mgg}^{-1}\right)$, Ficusreligiosa $\left(9.77 \mathrm{mgg}^{-1}\right)$, 
followed by Pongamiaglabra (9.25 $\left.\mathrm{mgg}^{-1}\right)$, Azardiractaindica $\left(9.12 \mathrm{mgg}^{-1}\right)$ and Polyalthialongifolia $\left(8.01 \mathrm{mgg}^{-1}\right)$. These findings were in agreement with the studies of Wagh et al., ${ }^{14}$ who have also reported reduction in protein content in A. indica, F. religiosa, $F$. bengalalensis and $T$. catapa while working under different traffic densities. Tectonagrandis (14.1 mgg ${ }^{-1}$ ), Ficusreligiosa (11.2 $\mathrm{mgg}^{-1}$ ) followed by Pongamiaglabra (11 mgg $\left.{ }^{-1}\right)$ Ficus bengalensis $\left(9.12 \mathrm{mgg}^{-1}\right)$ and Polyalthialongifolia $\left(8.01 \mathrm{mgg}^{-1}\right)$ showed decrease in protein content at site 3 (industrially polluted area) compared to control area. However, another study by Malhotra ${ }^{15}$ suggests that the reduction in the protein content is a result of its breakdown into free amino acids. The total soluble protein contents of trees in polluted area were significantly decreased compared with the same in unpolluted areas.

Similar results have been achieved by Ahmed et. al., ${ }^{16}$ that pollution from car exhaust and industries caused decrease in Chlorophyll and protein contents of some tree plants. The reduction in the total soluble protein content may be attributed to the reduction in the rate of photosynthesis due to the structural modification (damages) of polluted leaves such as formation of sunken stomata or deposition of thick layer of wax on the leaf surfacewhich may retard gases exchange. Also, the reduction in total soluble protein content of polluted plants may be due to an increase in the degradative enzyme activity such as proteases which catalyses the breakdown of polypeptides into amino acids to resist the stress induced by pollution ${ }^{17}$.

Reduction in protein content might be due to the enhanced rate of protein denaturation. The enhanced protein denaturation and breakdown of existing protein to amino acid is the main cause of reduction in protein content. The reduction in protein content might be due to the results of decreased photosynthesis on the other hand, decrease in protein content could be attributed either to break down of existing protein or due to reduced de novo synthesis.

Decrease in the total protein content is evident in leaves of soyabean after fumigation with elevated levels of $\mathrm{SO}_{2}+\mathrm{NO}_{2}$ mixture. It was observed the leaf damage and decrease in the protein content after $\mathrm{NO}_{2}$ fumigation. In another report decline in total protein content after fumigation with sulphur dioxide has been reported for a number of plants. Agrawal and Deepak ${ }^{18}$ determined that $\mathrm{SO}_{2}$ enrichment results in diminish leaf protein levels by $13 \%$ and suggested that such decrease could be attributed to break down of existing protein and reduction in synthesis.

The reduction in total protein content in leaf extract was not statistically significant in trees like Azardiractaindica and Eugineajambolana at site 2 and Delonixregia at site 3. Results obtained from Bradford method of protein estimation proteins in the control and air pollution conditions are consistent with results obtained by Helender et al., ${ }^{19}$ Who did not observe any significant difference between protein bands of polluted and control areas. Studies on Lagerstroemia indica showed a reduction in total protein content and a subsequent lower staining intensity of proteins under air pollution conditions. Studies on protein content of leaves show contradictory results.

At site 2, the maximum increase of protein content of leaves was observed in M.olifera $\left(9.1 \mathrm{mgg}^{-1}\right)$ and minimum was shown by the tree species T.indica $\left(3.02 \mathrm{mgg}^{-1}\right)$. The analyzed plants are arranged according to the order of increase of protein content which follows the order T.indica $<$ E.globulus $<$ F.benhalensis $<$ M.olifera. At site 3 , the maximum increase was observed in Eucalyptus globulus $\left(4.8 \mathrm{mgg}^{-1}\right)$ and the minimum was recorded in M.olifera $\left(0.32 \mathrm{mgg}^{-1}\right)$. The selected trees can be arranged based on the order of increase in the varying concentration of total soluble protein content. It is given in the following order; M.olifera $<$ T.indica $<$ M.indica $<$ T.grandis.Total protein content was reduced in trees exposed to polluted air. These results are similar to those of other researchers but Helender et al., ${ }^{19}$ showed the proteins not to be affected by air pollution. 
However, Beg and Farooq ${ }^{20}$ found that protein synthesis was enhanced and chemical contents (amino acid and carbohydrate) increased in $\mathrm{SO}_{2}$ sensitive plants (Tamarindusindica and Mangifera indica) whereas protein synthesis was retarded and chemical contents decreased in plant (Psidiumguajuva) resistance to sulfur dioxide. Zedler et al., ${ }^{21}$ recorded that protein content remain constant in leaves when exposed to atmospheric pollution. Tree species like T.indica $\left(3.02 \mathrm{mgg}^{-1}\right)$, M.olifera $\left(9.1 \mathrm{mgg}^{-1}\right)$, F.benhalensis (7.2 mgg $\mathrm{mg}^{-1}$ and E.globulus $\left(4.99 \mathrm{mgg}^{-1}\right)$ showed increase of protein content at site 2 and the plants showed considerable increase of soluble protein content such as E. globulus followed by M. indica, E. jambolona at site 3. Tree species like M.olifera $\left(0.32 \mathrm{mgg}^{-1}\right)$ followed by T.indica $\left(1.34 \mathrm{mgg}^{-1}\right)$ showed no significant increase at site 3 . The quantitative changes in certain polypeptides may be attributed to air pollution induced stress. Most of the polypeptides detected in the leaves were low molecular weight polypeptides weight polypeptides which appeared to be enzymes and /or heat shock proteins. B. Zedler and R. Plarre ${ }^{21}$ found out that most of the low molecular weight proteins are considered to be stress proteins which have been synthesized due to the stress effects.

\section{Conclusion}

The identification of a range of parameters of general use indocumenting air pollution stress-induced alteration in plants is important to physiological ecologists. However, identifying the mechanisms by which these alterations occurred is also important to understanding the relevance of observed responses to whole-plant physiological function. The combined effects of air pollutants on photosynthesis and translocation noted in this and earlier studies indicate that alteration of carbohydrate metabolism. Air pollutants independently effects enzymes that regulate the metabolism and translocation of carbohydrates while Tingey ${ }^{13}$ suggested that the retention of carbohydrates in leaves could cause reduction in photosynthesis by feedback inhibition and reduce the amount of assimilates for translocation to sinks within the plant. Variation in carbohydrate response to pollution stress may reflect difference in pollutants concentrations growth stages, species, cultivars within species. Also, pollution tolerance has been associated with several biochemical characteristics such as higher concentrations of reducing sugars. It is evident from this research that the flow of the carbohydrates from the source to the sinks was affected by increased levels of studied gases.

Changes in protein profiles may suggest a modification in gene expression and this was exhibited in $D$. regialeaves. The quantitative changes in certain polypeptides may be attributed to air pollution induced stress. Helender et al., ${ }^{19}$ who did not observe any significant difference between protein bands of polluted and control areas. In addition, Parui et al., ${ }^{22}$ found a decrease in protein concentration under air pollution. Plant species differ in their response to air pollution. Until now there is no comparable data on impact of pollution on protein. Taken together, studies on protein show contradictory results therefore this matter needs to be studied further.

\section{Acknowledgment}

Authors gratefully acknowledge the Director A .Shanmugasundaram and the managing board of VHNSN College, Virudhunagarfor having given me the opportunity to do research work.

\section{Reference}

1. Joshi P C and Swami A, Environmentalists, 2007, 27, 365-374. 
2. Agarwal M, Singh S B, Agrawal J N B and Bell Marshall F, Water Air Soil Pollution, 2006, 169(1-4), 239-254; DOI:10.1007/s11270-006-2237-6.

3. $\quad$ Krupa S V and Kickert R N, Environ Pollut., 1989, 61(4), 263-393;

DOI:10.1016/0269-7491(89)90166-8.

4. Tripathi A K and Mukesh Gautham, J Environ Biol., 2007, 28, 127-132.

5. Bradford M M, Anal Biochem., 1976, 72(1-2), 248-254;

DOI:10.1016/0003-2697(76)90527-3.

6. Hensen J and Moller J, Anal Biochem., 1975, 68(1), 87-94; DOI10.1016/00032697(75)90682-X.

7. Woo S Y, Lee D K and Lee Y K, Photosynthetica, 2007, 45(2), 293-295; DOI:10.1007/s11099-007-0047-8.

8. $\quad$ Agbaire P O, Int J Phys Sci., 2009, 4(6), 366-368.

9. Ziegler I, Planta, 1972, 103(2), 155-163; DOI:10.1007/BF00387367.

10. Miller P R, Parmete J R, Flick B H and, Martinez C W, J Air Pollut Control Assoc., 1969, 19(6), 435-438; DOI:10.1080/00022470.1969.10466510.

11. Rowland-Bamford A J, Baker J T, Allen L H and Bowes G, Env Exp Botany, 1996, 36(1), 111-124; DOI:10.1016/0098-8472(95)00025-9.

12. Godzik S and Ormrod H F, Environ Pollut., 1974, 7, 25-38;

DOI:10.1016/0013-9327(74)90004-4.

13. Tingey D T, InDugger, M(ED) Air pollution effects on plant growth ACS, Washington DC, 1974, 40-57.

14. Wagh N D, Shukla P V, Tambe B S and Ingle S T, J Env Biol., 2006, 27(2), 419-421.

15. Malhotra S S and Sarkar S K, Physilogia Plantarum., 1979, 47(4), 223-228; DOI:10.1111/j.1399-3054.1979.tb06517.x.

16. Ahmed S, Ismail F and Majeed J, J Sci Ind Res., 1986, 29(6), 464-467.

17. Dohmen G P, Koppers A and Langebartels C, Environl Pollut., 1990, 64(3-4), 375-383; DOI:10.1016/0269-7491(90)90059-L.

18. Agarwal Madoolika and Singh Deepak S, Environ Pollut., 2003, 121(2), 189-197; DOI:10.1016/S0269-7491(02)00222-1.

19. Helender M L, Savolainen J and Ahlholm J, Allergy, 1997, 52(12), 1207-1214; DOI:10.1111/j.1398-9995.1997.tb02525.x.

20. Beg M U and Farooq M O H D, Water Air Soil Pollut., 1988, 40(3-4), 317-326; DOI:10.1007/BF00163736.

21. Zedler B, Plarre R and Rothe G M, Environ Pollut., 1986, 40(3), 193-212; DOI:10.1016/0143-1471(86)90094-2.

22. Parui S, Mondal A K and Mandal S, Grana., 1998 , 37, 121-124. 